\title{
PEMBUATAN WEBSITE SEBAGAI OPTIMALISASI PROMOSI PELAYANAN KLINIK PRATAMA BRASTOMOLO TEMANGGUNG
}

\author{
Making A Website As A Promotion Optimization Services at Pratama Clinic Brastomolo of \\ Temanggung
}

\author{
Mukhamad Musta'in ${ }^{1}$, Suamanda Ika Novichasari ${ }^{2}$ \\ ${ }^{1}$ Prodi Diploma Tiga Keperawatan Fakultas Keperawatan Universitas Ngudi Waluyo Ungaran \\ ${ }^{2}$ Prodi S1 Teknik Informatika Fakultas Ilmu Pendidikan dan Teknologi Informasi Universitas \\ Ngudi Waluyo Ungaran \\ Email: mukhamadmustain@gmail.com
}

\begin{abstract}
Abstrak
Perkembangan teknologi saat ini sangat mendukung digunakan sebagai sarana promosi dan informasi. Khususnya pada bidang website yang saat ini menjadi media informasi yang menawarkan berbagai kemudahan dalam menyajikan informasi. Website lebih mudah diakses oleh masyarakat di berbagai daerah hanya dengan menggunakan internet. Salah satunya dalam hal pemasaran produk suatu usaha, website dapat menjadi sarana mempromosikan, memasarkan dan menyampaikan informasi yang efektif dan efisien kepada masyarakat. Pembuatan website untuk pemasaran sebuah produk sangat diperlukan salah satunya bagi sector kesehatan. Tidak terkecuali klinik pratama Brastomolo yang berkecimpung di pelayanan kesehatan seperti pelayanan kedokteran, keperawatan dan apotek. Tujuan kegiatan ini adalah peningkatan pengetahuan staff tentang pembuatan web dan mengenalkan klinik brastomolo ke masyarakat melalui media web. Metode yang digunakan adalah melakukan penulusuran web klinik, selanjutnya pelaksanaan pelatihan pembuatan web klinik pratama Brastomolo. Hasil dari kegiatan pengabdian masyarakat ini adalah pemahaman staff dalam kategori baik (64\%), pengetahuan cukup (33\%) dan pembuatan web masih dalam tahap pengembangan. Dapat disimpulkan bahwa kegiatan pengabdian masyarakat berjalan baik dan diperlukan monitoring perkembangan web secara berkala.

Kata kunci: website, brastomolo
\end{abstract}

\section{Abstract}

The development of technology is currently very supportive to be used as a means of promotion and information. Especially in the area of the website which is currently an information medium that offers various conveniences in presenting information. The website is more easily accessible to people in various regions by simply using the internet. One of them is in terms of marketing the products of a business, the website can be a means of promoting, marketing and conveying information effectively and efficiently to the public. Creating a website for marketing a product is needed, one of which is for the health sector. The Brastomolo clinic is no exception, which is involved in health services such as medical services, nursing services and pharmacies. The purpose of this activity is to increase staff knowledge about web development and introduce the Brastomolo clinic to the public through web media. The method used was conducting clinical web searches, then implementing training in making the clinic web development at Pratama Brastomolo. The result of this community service activity is the understanding of the staff in the good category (64\%), sufficient knowledge (33\%) and web development is still in the development stage. Thus it can be concluded that community service activities are running well and periodic monitoring of web development is required.

Keywords: website, brastomolo 


\section{PENDAHULUAN}

Dampak dari perkembangan dunia Teknologi Informasi dan Komunikasi (TIK) pada saat ini peningkatan akses terhadap internet mulai mengubah gaya hidup manusia dalam berbagai aspek, baik itu di dalam bidang ekonomi, politik, hingga kehidupan sosial masyarakat saat ini sudah diwarnai dengan kecanggihan dunia Teknologi Informasi dan Komunikasi (Sundari, 2019).

Internet menurut Prayudi (2008) memberikan peluang tambahan untuk memperbaiki citra dan reputasi perusahaan atau organisasi. Dengan perkembangan tersebut, menuntut pihak-pihak manajemen organisasi lebih bertanggung jawab serta responsif terhadap kebutuhan publik. Menurut Mc Quaill dalam Prayudi (2008) internet merupakan sebuah media dengan segala karakteristiknya. Internet memiliki teknologi, cara menggunakan, lingkup pelayanan, dan isi serta image tersendiri.Internet tidak dimiliki, dikendalikan atau dikelola oleh sebuah badan tunggal, tetapi merupakan sebuah jaringan komputer yang terhubung secara internasional dan beroperasi berdasarkan protokol yang disepakati bersama. Sejumlah organisasi, khususnya service provider dan badan telekomunikasi berperan dalam operasi internet.

Pelayanan kesehatan menghadapi banyak tantangan termasuk peningkatan usia harapan hidup yang cenderung mengubah pola penyakit populasi, kebutuhan pemeliharaan sumber daya kesehatan, peningkatan Ilmu Pengetahuan dan Teknologi (IPTEK) kedokteran dan pelayanan kesehatan yang berkembang secara pesat diiringi oleh minat konsumen dalam mengakses informasi melalui internet. Menghadapi semua tantangan ini, organisasi pelayanan kesehatan harus mampu mengoperasikan sistem pelayanannya secara efisien dan efektif (Hatta, 2008).

Klinik Pratama Brastomolo merupakan klinik pelayanan kesehatan yang memberikan pelayanan medis, keperawatan, dan apotek. Lokasi klinik tersebut sangat strategis tepat berada dipinggir jalan raya 
kota Temanggung. Karena keterbatasan sumber daya manusia di bidang teknologi klinik ini belum memiliki website tersendiri terkait fasilitas yang ditawarkan, sehingga belum banyak masyarakat yang mengetahui keberadaaan dan fasilitas yang ditawarkan klinik tersebut.

Dengan pemberian pelatihan pembutan website diharapkan staff mampu membuat web/ mengelola web dan dampaknya masyarakat tahu keberadaan klinik sehingga mau untuk berobat ke klinik tersebut.

\section{TUJUAN}

Tujuan pelatihan ini adalah:

1. Meningkatnya pengetahuan staff tentang pembuatan web.

2. Terbentuknya website klinik.

3. Dikenalnya klinik oleh masyarakat melalui web.

\section{PELAKSANAAN}

A Sasaran dan Metode kegiatan yang digunakan.

Sasaran pengabdian adalah staff klinik pratama Brastomolo Kab Temanggung. Metode yang digunakan melalui pelatihan pembuatan web dan pengelolaanya. Evaluasi dilakukan berdasar pemahaman staff dan tercapainya program yaitu terbentuknya website klinik.

B. Waktu dan Tempat Kegiatan. Pengabdian masyarakat dilakukan di Klinik Pratama Brastomolo pada tanggal 8 Agustus 2020. Kegiatan di mulai jam 08.00 WIB hingga 11.00 WIB.

C. Materi

Materi yang disampaikan meliputi :

1. Website, Domain dan Hosting

2. Membuat dan Managemen web 


\section{HASIL DAN PEMBAHASAN}

\section{HASIL}

Peserta pelatihan merupakan staf di klinik berjumlah 3 orang baik laki- laki ataupun perempuan yang dapat dilihat pada tabel 1 berikut.

Tabel 1 Distribusi Frekuensi peserta pelatihan berdasar jenis kelamin

\begin{tabular}{llcc}
\hline No & \multicolumn{1}{c}{$\begin{array}{c}\text { Jenis } \\
\text { Kelamin }\end{array}$} & Frek & $\begin{array}{c}\text { Prosentase } \\
(\%)\end{array}$ \\
\cline { 2 - 2 } 1 & Laki- laki & 2 & $\underline{66 \%}$ \\
2 & $\frac{\text { Perempuan }}{\text { Total }}$ & $\underline{1}$ & $\underline{34 \%}$ \\
\hline & $\underline{3}$ & $\underline{100 \%}$ \\
\hline
\end{tabular}

Distribusi peserta berdasarkan profesi dapat dilihat pada tabel 2 berikut:

Tabel 2 Distribusi Frekuensi peserta berdasarkan Profesi

\begin{tabular}{llcc}
\hline No & Profesi & Frekuensi & $\begin{array}{c}\text { Prosentase } \\
(\%)\end{array}$ \\
1 & Dokter & 1 & $33 \%$ \\
2 & Perawat & 1 & $33 \%$ \\
3 & Apoteker & $\underline{1}$ & $\underline{34 \%}$ \\
\cline { 1 - 1 } & $\underline{\underline{T}}$ & $\underline{3}$ & $\underline{100 \%}$ \\
\hline
\end{tabular}

Berdasarkan tabel 2 dapat bahwa peserta kegiatan diikuti oleh tenaga kesehatan

smoxapSAAA.kelas yang banyak digemari oleh Tabel 3 Distribusi Frekuensi peserta berdasarkan Pemahaman materi

\begin{tabular}{|c|c|c|c|}
\hline No & Profesi & Frekuensi & $\begin{array}{c}\text { Prosentase } \\
(\%)\end{array}$ \\
\hline 1 & Sangat baik & - & $0 \%$ \\
\hline 2 & Baik & 2 & $66 \%$ \\
\hline 3 & Cukup & $\underline{1}$ & $34 \%$ \\
\hline 4 & Kurang & - & $0 \%$ \\
\hline & Total & 3 & $100 \%$ \\
\hline
\end{tabular}

Berdasarkan tabel 3 dapat bahwa peserta dengan pemahaman materi kategori baik.

Tingkatan Pengelolaan web Website klinik pratama brastomolo masih dalam tahap pengembangan dan dapat dilihat dialamat web yaitu klinikbrastomolo.com

\section{PEMBAHASAN}

Perkembangan teknologi banyak digunakan sebagai sarana promosi dan informasi khususnya pada bidang website yang saat ini menjadi media informasi yang menawarkan berbagai kemudahan dalam menyajikan informasi. Kecepatan dan kenyamanan merupakan nilai positif adanya internet. Website lebih mudah diakses oleh masyarakat di berbagai daerah hanya dengan menggunakan internet. Salah satunya dalam hal pemasaran produk suatu usaha, website dapat menjadi sarana mempromosikan, memasarkan dan menyampaikan informasi yang efektif dan efisien kepada masyarakat (Hasugian, 2018).

Pembuatan website untuk pemasaran sebuah produk sangat diperlukan bagi sector kesehatan. Dengan promosi lewat web maka akan mudah dikenal oleh masyarakat. Pengenalan sebuah klinik kesehatan melalui web juga perlu dilakukan, tidak terkecuali klinik pratama Brastomolo yang berkecimpung di pelayanan kedokteran, keperawatan dan apotek.

Hasil evaluasi setelah pelatihan pembutan website di klinik pratama Brastomolo berdasar tabel 3 dapat dilihat bahwa, tingkat pengetahuan dalam pembuatan website peserta berada pada kategori baik sejumlah 64\%, dan cukup sejumlah 33\%. Hal ini sangat wajar karena materi yang diajarkan merupakan materi yang baru dan diperlukan ketekunan dalam memahami materi yang disajikan. Pengetahuan adalah hasil dari tahu yang terjadi setelah seseorang melakukan penginderaan terhadap suatu objek tertentu. Penginderaan terjadi melalui panca indera manusia, yakni indra penglihatan, pendengaran, penciuman, rasa dan raba, sebagian besar pengetahuan manusia diperoleh melalui mata dan telinga.

Pengetahuan adalah factor dominan yang sangat penting untuk terbentuknya tindakan seseorang (Notoatmodjo, 2007). 
Menurut Azwar (1983) dalam Machfoedz (2007) dijelaskan bahwa penyuluhan merupakan pendidikan yang dilakukan 
dengan cara menyebarkan pesan, penanaman keyakinan sehingga masyarakat tidak hanya sadar, tahu dan mengerti, tetapi juga mau dan bisa melakukan suatu anjuran. Mubarak (2007) menjelaskan informasi merupakan salah satu factor yang mempengaruhi pengetahuan karena kemudahan untuk memperoleh suatu informasi dapat membantu mempercepat seseorang untuk memperoleh pengetahuan yang baru.

Pembuatan website klinik pratama Brastomolo juga sebagai sarana promosi ke masyarakat dan diharapkan masyarakat mau berobat ke klinik tersebut. Hasiguan (2018) menjelaskan dengan adanya promosi produsen atau distributor mengharapkan kenaikannya angka penjualan. Fungsi promosi dalam bauran pemasaran adalah untuk mencapai berbagai tujuan komunikasi dengan konsumen. Dimuat dalam jurnal Denny Daud (2013) bahwa menurut Babin (2011) Promosi merupakan fungsi komunikasi dari perusahaan yang bertanggung jawab menginformasikan dan membujuk atau mengajak pembeli.

\section{DAFTAR PUSTAKA}

Daud, Denny. (2013). Promosi dan Kualitas Layanan Pengaruhnya Terhadap Keputusan Konsumen Menggunakan Jasa Pembiayaan Pada PT.Bess Finance Manado. Jurnal EMBA. 1(4), 52.

Hasugian, PS. (2018). Perancangan Website Sebagai Media Promosi dan Informsi. Jornual Of Informatic Pelita Nusantara Vol 3 No 1. 1 Maret 2018. http://ejurnal.pelitanusantara.ac.id/index.php/ JIPN/article/view/306

Hatta, G. (2008). Pedoman Manajemen Informasi Kesehatan di Sarana Pelayanan Kesehatan. Jakarta: UI Press
Machfoedz Ircham, dan Suryani Eko.(2007). Pendidikan Kesehatan Bagian dari 
Promosi Kesehatan.

Yogyakarta. Fitramaya.

Mubarak. 2007. Promosi Kesehatan Sebuah Pengamatan Proses Belajar Mengajar dalam Pendidikan. Jokjakarta: Graha Ilmu.

Notoadmojo, S. (2007). Pendidikan dan Perilaku Kesehatan. Jakarta: PT Rineka Cipta

Prayudi, Ahmad. (2008). Manajemen Isu Pendekatan Public Relations.
Yogyakarta: Piss Printing.

Sundari, Heni dan Rahayu, Sri. (2019). Pengaruh Kompetensi Sumber Daya Manusia, Pemanfaatan Teknologi Informasi, Dan Sistem Pengendalian Intern Terhadap Kualitas Laporan Keuangan (Studi Kasus Pada Satuan Kerja Perangkat Daerah Kota Bandung Tahun 2018). eProceeding of management. Vol 6 No 1 . https://libraryeproceeding.telkomuniv ersity.ac.id/index.php/management/art icle/view/8649/8516 